\title{
Determinants of Distributor's Satisfaction on Multi Level Marketing [MLM] Strategies
}

\author{
O.S. Vedavalli, M. Venkatramaraju
}

\begin{abstract}
The present study helps to bring out the various factors that determine the distributor's satisfaction towards multi level marketing strategies in their business. This study adopted survey method and questionnaire method to collect primary information from the distributors of multi level marketing in their regular business practices. The five different factors have been studies to explore the distributor's perception. Perceived quality on the training program was not significantly influence the distributor's satisfaction. This empirical investigation explores that distributors of multi level marketing companies are having higher perception on multi level marketing strategies.
\end{abstract}

Keywords: Multilevel Marketing, Distributors satisfaction, Perception and Opportunity.

\section{INTRODUCTION}

Multi level marketing is the process of recruiting new distributors to help and facilitate the existing distributors for the purpose of increasing the direct sales of goods and services. Multi level marketing helps the distributors to increase the sales of the firm by providing certain percentage of the profit as commission to newly recruited distributors. Multi level marketing helps the sellers to increase the sales by individual referrals and word of mouth promotion. The sales persons and distributors are sells the products and simultaneously they encourage other to join in the process to sell it to other customers. The newly recruited distributors are also called as down line participants or down line distributors. The companies like, Tupperware and Amway are the most popular companies successfully adopted the multi level marketing in their regular business practices.

Revised Manuscript Received on December 05, 2019.

* Correspondence Author

O. S. Vedavalli*, Research Scholar (Part-Time), Department of Commerce, Pachaiyappa's College, Chennai, India - Assistant Professor \& Head, St. Joseph's College (Arts \& Science), Chennai, India. Email: ossrivedavalli@gmail.com

Dr. D. Venkatramaraju, Associate Professor \& Research Supervisor (Rtd.), Department of Commerce, Pachaiyappa's College, Chennai, India. Email: prof.dvraju@gmail.com

\section{A. History of Multi-Level Marketing Industry}

Multi-level marketing (MLM) is also known as director selling or network selling or referral selling. This innovative method of marketing initially helped many distributors to sell their products quickly and also to the large number of customers. There are two type of multi level marketing is generally adopted by many companies such as, Single Level Marketing and Multi Level Marketing. Single level marketing is always selling and distributing to one to one method. Single level marketing required no intermediaries for the purpose personal selling. Whereas, multi level

marketing makes the importance of intermediaries to connect and contact more number of customers for one particular product or service.

\section{B. Direct Selling}

Direct selling method was emerged to overcome the different malpractices and exploitation happened in the process of buying and selling the goods and services across different types of markets. Direct selling is one of the oldest method of selling the goods and services as compared to other innovative new marketing strategies. Direct selling method helps to create healthy relationship among the customers and distributors which facilitates the customer retention for the over a period of time.

\section{REVIEW OF LITERATURE}

Koehn (2001) conducted a study on ethics in multi level marketing and found that its helps the firm to grow much faster than any other traditional marketing strategies.

Chang and Tseng (2005) conducted a case study on multi level marketing strategies of Taiwanese companies and explored that customers are important capital for the companies and effective relationship between customers and distributors will increase the sales of the products.

Emek et. al (2011) carried study to examine the mechanisms of multi level marketing that helps to motivates the participants to perform better and effectively for the purpose of maximizing the sales and profits of the companies.

Albaum \& Peterson (2011) investigated the objectivity of multi level marketing for the purpose of effective networking and the results proves that it has significant influence on the networking capability of the distributors. 
Constantin (2009) analysed the relationship marketing effectiveness with the tool of multi level marketing. The result of the empirical investigation proves that relationship marketing has significant and positive relationship between multi level marketing effectiveness of companies.

The existing body of knowledge lacks in determinants of distributors satisfaction and perception on multi level marketing companies. So, it was taken as a research gap of the study to explore further and add new knowledge to the existing body of knowledge.

\section{OBJECTIVES OF THE STUDY}

1. To explore the influence of distributors perception on the satisfaction level towards multi-level marketing (MLM) companies.

2. To examine and study the personal and demographic profile of the multi-level marketing (MLM) companies distributors.

\section{RESEARCH METHODOLOGY}

This study was adopted exploratory and descriptive research design to conduct survey from the distributors of various companies adopts multi level marketing as tool to market their goods and services. This study adopted convenience sampling method to gather primary data from distributors of multi level marketing companies.

The sample of 103 were collected and subjected to analysis using SPSS version 23.0. The statistical tools such as, percentage analysis has been applied to study the personal and demographic profile of the respondents. Whereas, multiple regression analysis has been applied to explore the significant influencers of distributor's satisfaction towards multi level marketing.

\section{DATA ANALYSIS AND INTERPRETATION}

\section{A. Demographic Profiles of the Distributors Participated in the Study:}

Majority of the respondents are males $(67.0 \%)$, married $(56 \%)$ and hailing from nuclear families $(90.0 \%)$. Majority of the respondents are educated at under-graduate level (89\%) and working as a distributor for nearly 5 years (52\%). The respondents are earning upto Rupees 25, 000 (53\%) and they distribute FMCG products $(89 \%)$.

B. Influence of Distributors Perception on Multi Level Marketing on their Level of SatisfactionMethod of Diffusing Business Opportunity:
Table 1

Regression Results of Influence of Distributors Perception on Multi Level Marketing on their Level of Satisfaction

\begin{tabular}{|c|c|c|c|c|c|c|c|c|}
\hline $\begin{array}{c}\text { Dependent } \\
\text { Variable }\end{array}$ & $\begin{array}{l}\text { Independent } \\
\text { Variables }\end{array}$ & $\begin{array}{l}\text { Mean } \\
\text { (SD) }\end{array}$ & $\begin{array}{l}\text { F- } \\
\text { Value }\end{array}$ & $\mathbf{R}$ & $\mathbf{R}^{2}$ & $\underset{\mathbf{R}^{2}}{\text { Adjusted }}$ & $\begin{array}{c}\beta \\
\text { (t-Value) }\end{array}$ & Sig. \\
\hline \multirow{6}{*}{$\begin{array}{l}\text { Distributors } \\
\text { Satisfaction }\end{array}$} & & $\begin{array}{l}18.231 \\
(3.14)\end{array}$ & 46.231 & 0.655 & 0.430 & 0.422 & & \\
\hline & $\begin{array}{l}\text { Method of diffusing } \\
\text { business opportunity }\end{array}$ & $\begin{array}{l}12.321 \\
(1.51)\end{array}$ & & & & & $\begin{array}{c}0.176 \\
(3.762)\end{array}$ & $<0.001 * * * *$ \\
\hline & $\begin{array}{l}\text { Perceived quality of } \\
\text { recruiting process }\end{array}$ & $\begin{array}{l}10.213 \\
(1.52)\end{array}$ & & & & & $\begin{array}{c}0.245 \\
(5.670)\end{array}$ & $<0.001^{* * *}$ \\
\hline & Up-line support & $\begin{array}{l}17.891 \\
(1.59)\end{array}$ & & & & & $\begin{array}{c}0.242 \\
(5.695)\end{array}$ & $<0.001 * * *$ \\
\hline & $\begin{array}{ll}\text { Perception } & \text { on } \\
\text { products/services }\end{array}$ & $\begin{array}{l}12.321 \\
(1.60)\end{array}$ & & & & & $\begin{array}{c}0.191 \\
(4.385)\end{array}$ & $<0.001$ **** \\
\hline & $\begin{array}{l}\text { Quality of training } \\
\text { program }\end{array}$ & $\begin{array}{l}8.783 \\
(0.84)\end{array}$ & & & & & $\begin{array}{l}0.138 \\
(3.204)\end{array}$ & 0.421 \\
\hline
\end{tabular}

Table 1 reveals that OLS Model has a goodness of fit for multiple regression analysis and the linear combination of Method of diffusing business opportunity, perceived quality of recruiting process, up-line support and perception on products/ is significantly related to distributor's satisfaction, $\{\mathrm{F}=46.231, \mathrm{p}<0.001\}$. The multiple correlation coefficient is 0.655 , indicating that $43.0 \%$ of the variance of the distributors satisfaction in the order of influence, is accounted by linear combination. Method of diffusing business opportunity, perceived quality of recruiting process, up-line support and perception on products significantly and positively influence distributors satisfaction. Whereas, perceived quality of training program do not have significant influence on the distributors satisfaction.

\section{IMPLICATIONS AND CONCLUSION}

.This empirical investigation explores that distributors of multi level marketing companies are having higher perception on multi level marketing strategies. They opine that multi level marketing is very helpful to create a network among interested distributors for one particular product and services to increase the customer base for the purpose of maximizing the sales of the company. Multi level marketing plays a significant role in increasing the sales of the product and also helps the distributors to attain their periodical targets. The factors such as, Method of diffusing business opportunity, perceived quality of recruiting process, up-line support and perception on products significantly and positively influence distributors satisfaction whereas, perceived quality of training program do not have significant influence on the distribution satisfaction. Therefore, the training for the new recruited distributors should be nurtured more effectively for the purpose of reaching the targets of distributors.

\section{REFERENCES}

1. Albaum, G., \& Peterson, R. A. (2011). Multilevel (network) marketing: An objective view. The Marketing Review, 11(4), 347-361.

2. Chang, A., \& Tseng, C. N. (2005). Building customer capital through relationship marketing activities: The case of Taiwanese multilevel marketing companies. Journal of Intellectual capital, 6(2), 253-266.

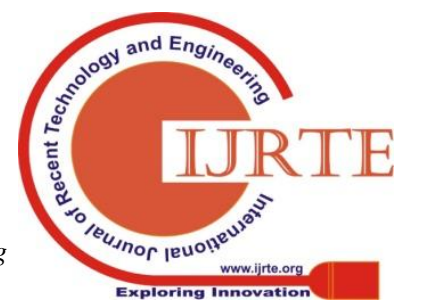


3. Constantin, C. (2009). Multi-level marketing-a tool of relationship marketing. Bulletin of the Transilvania University of Brasov. Economic Sciences. Series V, 2, 31.

4. Emek, Y., Karidi, R., Tennenholtz, M., \& Zohar, A. (2011, June) Mechanisms for multi-level marketing. In Proceedings of the 12th ACM conference on Electronic commerce (pp. 209-218). ACM.

5. Koehn, D. (2001). Ethical issues connected with multi-level marketing schemes. Journal of business ethics, 29(1-2), 153-160.

\section{AUTHOR PROFILE}

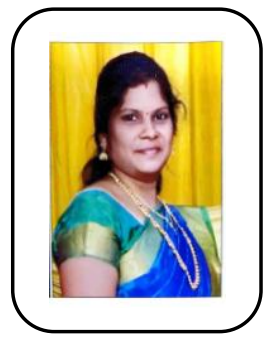

Mrs. Vedavalli. O.S who is heading the department of corporate secretaryship of st.Joseph's college (Arts \& Science) has submitted her thesis \& awaiting for viva from University of Madras. She has published 4 papers in UGC listed journal \& had presented papers in international \& state level conferences. Mrs.Vedavalli is passionate towards her profession. Her dream is to build a school \& give quality education to all capable \& eligible students. 